\title{
Potential Impact of Global Warming on Virus Propagation in Infected Plants and Agricultural Productivity
}

\author{
Khalid Amarit, Caiping Huang and Manfred Heinlein* \\ Institute of Plant Molecular Biology (IBMP), CNRS UPR 2357, Université de Strasbourg, Strasbourg, France
}

The increasing pace of global warming and climate instability will challenge the management of pests and diseases of cultivated plants. Several reports have shown that increases in environmental temperature can enhance the cell-to-cell and systemic propagation of viruses within their infected hosts. These observations suggest that earlier and longer periods of warmer weather may cause important changes in the interaction between viruses and their host's plants, thus posing risks of new viral diseases and outbreaks in agriculture and the wild. As viruses target plasmodesmata (PD) for cell-to-cell spread, these cell wall pores may play yet unknown roles in the temperature-sensitive regulation of intercellular communication and virus infection. Understanding the temperature-sensitive mechanisms in plant-virus interactions will provide important knowledge for protecting crops against diseases in a warmer climate.

Keywords: plant viruses, Tobacco mosaic virus, temperature, global warming, agriculture, plasmodesmata, tolerance

${ }^{*}$ Correspondence:

Manfred Heinlein

manfred.heinlein@ibmp-cnrs.unistra.fr

${ }^{\dagger}$ Present address:

Khalid Amari,

Julius Kühn Institute (JKI) - Federal Research Centre for Cultivated Plants,

Institute for Biosafety in Plant

Biotechnology, Quedlinburg, Germany

Specialty section:

This article was submitted to Plant Pathogen Interactions, a section of the journal

Frontiers in Plant Science

Received: 27 January 2021 Accepted: 03 March 2021

Published: 31 March 2021

Citation:

Amari $K$, Huang $C$ and Heinlein $M$ (2021) Potential Impact of Global

Warming on Virus Propagation in Infected Plants and Agricultural

Productivity.

Front. Plant Sci. 12:649768.

doi: 10.3389/fpls.2021.649768

\section{INTRODUCTION}

Viruses can cause major losses in crop yields and are the primary cause of emerging diseases in plants (Nicaise, 2014). As has been reviewed comprehensively, changes in temperature and other parameters of climate change (changes in rainfall patterns, wind, accumulation of greenhouse gases, and extreme weather events, to name a few) are expected to affect the geographic distribution of the viral hosts and vectors, and thus the epidemiology of viruses that depend on these hosts and vectors for propagation and inter-plant transmission (Canto et al., 2009; Jones and Barbetti, 2012). As global temperatures increase, poleward and higher altitude areas with currently colder weather likely assume a more temperate climate, whereas the regions with currently temperate climate become warmer and may assume a climate that is more typical for tropical zones. Thus, in response to global temperature increases, the viral hosts and vectors adapted to temperate climates are expected to spread with their viruses poleward and to higher altitudes where temperatures will then be temperate, whereas hosts and viral vectors in tropical regions will invade with their viruses the regions with a currently mild climate where temperatures may have increased toward values that are currently typical for tropical areas. In these newly invaded regions, virus hosts and vectors as well as their viruses may find conditions that are similar as in previous habitats, thus allowing them to interact as previously. From this point of view, a warmer climate is predicted to cause a global shift in the distribution of viruses along with their hosts and vectors. And, because this process may allow viruses to interact with their current hosts and vectors as previously, a strong global impact on virus propagation and virus-caused diseases in agriculture may not be expected. On the other hand, this view may be too simple. First, the new geographical locations 
may allow viruses to find new hosts, which poses risks of new emerging diseases (Jones, 2020). Second and more important, plants tolerate broad ranges of temperatures (Parent and Tardieu, 2012; Figure 1), and most of them will likely not migrate, at least not immediately. For canola and potato, for example, the ranges of temperatures for growth with at least $50 \%$ of the maximum rate are from 15.0 to $29.6^{\circ} \mathrm{C}$ and from 21.6 to $37.3^{\circ} \mathrm{C}$, respectively. For sunflower, which has a temperature optimum around $29^{\circ} \mathrm{C}$, the range is from 17.3 to $38.3^{\circ} \mathrm{C}$. The average high temperature currently reached in summer in London, Paris, or Berlin (23$25^{\circ} \mathrm{C} ;^{1}$ ) is below the temperature optima for crops grown in the area such as wheat, barley, potato, maize, or sunflower $(27.7,26.6$, 30.6, 30.8, and $29.3^{\circ} \mathrm{C}$, respectively; Parent and Tardieu, 2012). Thus, there is room for temperature increases until these and other plants are forced to migrate. According to current climate change projections by the Intergovernmental Panel on Climate Change (IPCC), the global mean surface temperature change for the period 2016-2035 relative to 1986-2005 will likely be in the range of $0.3-0.7^{\circ} \mathrm{C}$ and, dependent on prediction scenarios, may reach $0.3-4.8^{\circ} \mathrm{C}$ at the end of the 21 st century (2081-2100) (IPCC, 2014). These global changes in temperature are predicted to be accompanied by local weather extremes with heat waves and drought that cause significant yield losses (Bita and Gerats, 2013). However, except for plants currently growing in areas with conditions at their tolerance margins, these predicted changes in temperature will not cause an immediate global migration of all viruses and their hosts away from their current geographical zones. For most hosts and their viruses, expected movements to colder areas may occur only gradually, over long ranges of time. However, while these plants remain at their locations, warmer local temperatures will nevertheless already have immediate effects on the intracellular environment provided by these hosts to viruses, thus posing risks to agriculture.

Temperature is a physical parameter that influences biochemical reactions and higher molecular structures, like DNA and proteins, and supramolecular components, like membranes and the elements of the cytoskeleton, through simple thermodynamic effects (Ruelland and Zachowski, 2010). Warmer temperature thereby causes increased membrane fluidity and cytoskeletal dynamics, which can enhance the propagation of plant viruses that generally depend on these cellular components for replication and spread within their hosts. Consistently, numerous studies demonstrated that the rate at which viruses replicate and move through the infected plant increases with temperature up to a certain temperature optimum, beyond which viral propagation decreases. For example, Lebeurier and Hirth (1966) demonstrated already more than 50 years ago in Nicotiana tabacum leaf disks that Tobacco mosaic virus (TMV) increases its multiplication with temperature and that replication is again lower only when temperature reaches $34-36^{\circ} \mathrm{C}$. Later, with a green fluorescent protein (GFP)-tagged virus it was shown that the cell-to-cell spread in $N$. benthamiana plants was threefold stronger when the temperature was increased by 10 degrees (from 22 to $32^{\circ} \mathrm{C}$ ) (Boyko et al., 2000a,b). Similarly, Turnip mosaic virus (TuMV) showed increased accumulation in Chinese

${ }^{1}$ https://www.weather-atlas.com/en/

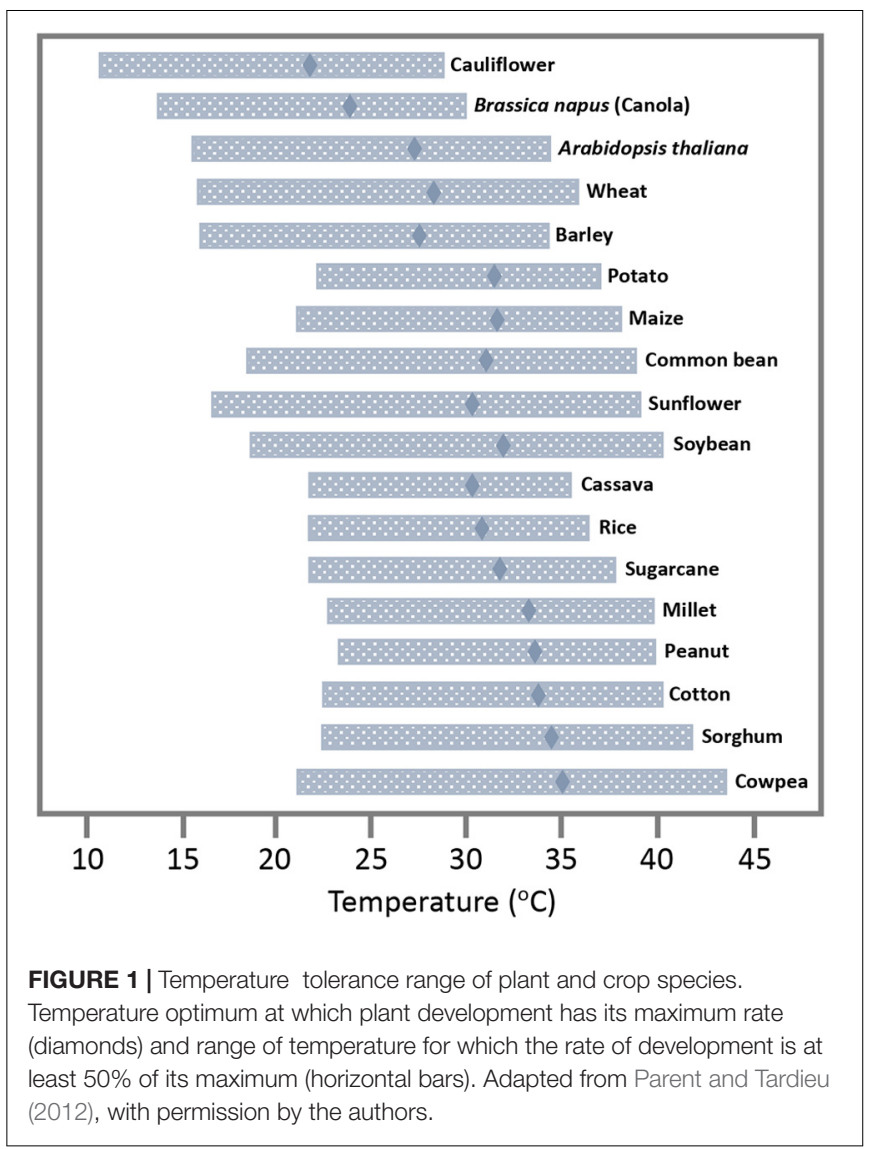

cabbage when temperature was increased from 13 to $23-28^{\circ} \mathrm{C}$ (Chung et al., 2015) and a GFP-tagged version of this virus shows a twofold more efficient cell-to-cell (Figures 2A,B) and systemic (Figures 2C,D) spread in canola (Brassica napus) upon shifting the daytime temperature by only four degrees from 24 to $28^{\circ} \mathrm{C}$. In Arabidopsis, TuMV was shown to accumulate to higher levels when kept at $25^{\circ} \mathrm{C}$ during the day and $15^{\circ} \mathrm{C}$ in the night as compared to colder temperatures with $15^{\circ} \mathrm{C}$ during the day and $5^{\circ} \mathrm{C}$ in the night (Honjo et al., 2020). Potato plants infected with Potato virus $Y$ showed a dramatic increase in systemic infection when temperatures were increased from 23 to $28^{\circ} \mathrm{C}$ (Choi et al., 2017). Barley yellow dwarf virus (BYDV) showed strong increases in systemic movement in oat when the temperature was elevated from 15.5 to $21^{\circ} \mathrm{C}$ (Jensen, 1973) and infection of bean leaves with Rothamsted tobacco necrosis virus (RTNV) increased with rising temperature from 10 to $22^{\circ} \mathrm{C}$ (Harrison, 1956). The spread and replication of Wheat streak mosaic virus and disease development in Winter Wheat was shown to increase with temperature within the tested temperature range of $10-27^{\circ} \mathrm{C}$ (Wosula et al., 2017). Given that virus accumulation and disease symptoms are often correlated, these examples hint toward the imminent risk that earlier and longer periods of warmer weather will aggravate virus-induced diseases in crops in their current growing areas, thus endangering yields.

The risks imposed by global warming may not be limited to viruses in crops, however. It is often overlooked that viruses are 
A
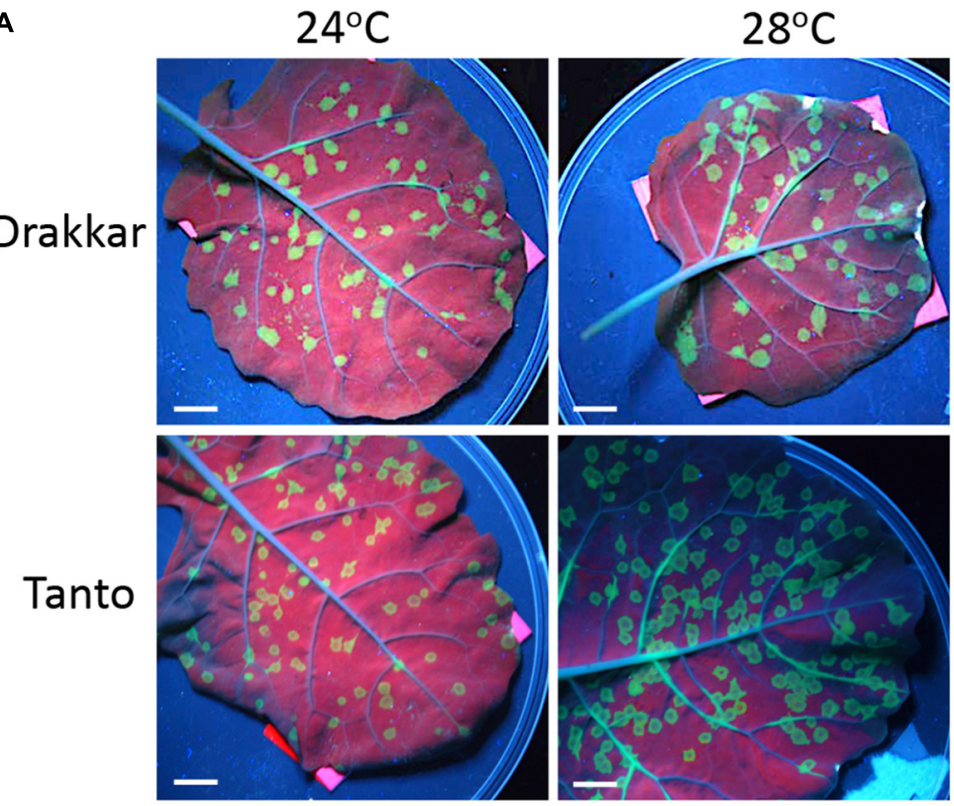

C
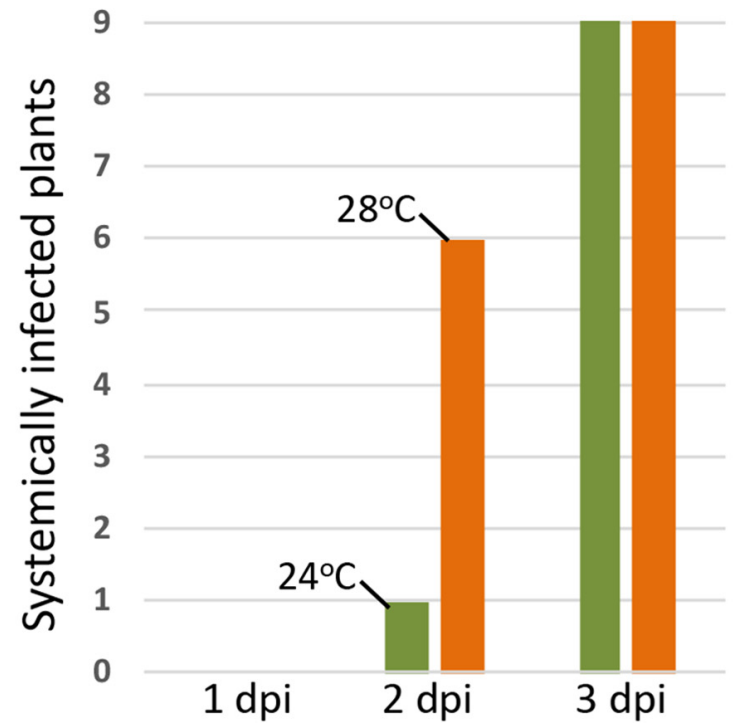

B

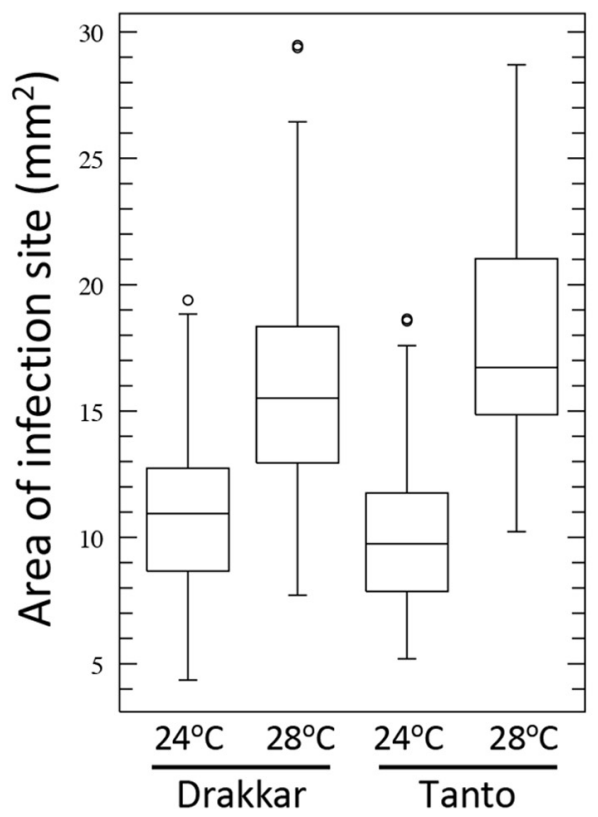

D

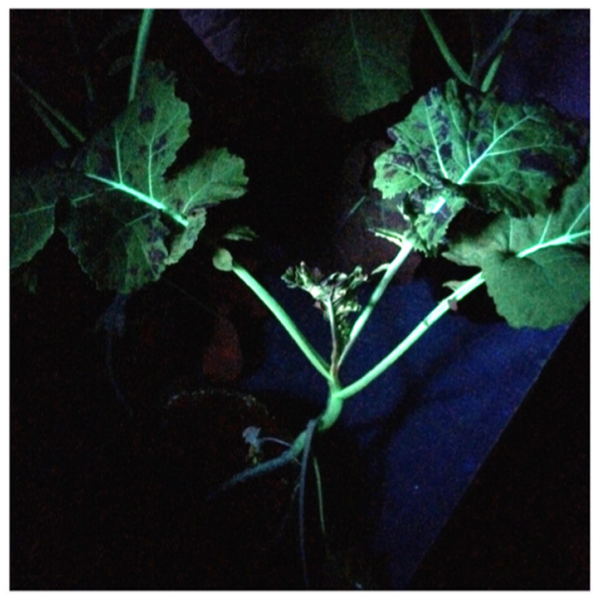

FIGURE 2 | Temperature effect on TuMV-GFP infection in B. napus cultivars Drakkar and Tanto. Plants were incubated at $20^{\circ} \mathrm{C}$ for $8 \mathrm{~h}$ (night) and $24^{\circ} \mathrm{C}$ for $16 \mathrm{~h}$ (day) until two leaf stage. Half of the plants were then transferred to $20^{\circ} \mathrm{C}$ for $8 \mathrm{~h}$ (night) and $28^{\circ} \mathrm{C}$ for $16 \mathrm{~h}$ (day). Plants were allowed to adjust for 2 days before inoculation. (A) Effect of temperature on viral cell-to-cell spread in inoculated leaves. Pictures were taken at 6 days post inoculation (6 dpi) under UV light. Scale bar, $1 \mathrm{~cm}$. (B) Sizes of individual local infection sites at $6 \mathrm{dpi}$. Infection foci in leaves of five plants per condition were measured $\left(\operatorname{Drakkar} 24^{\circ} \mathrm{C}, N=117\right.$; Drakkar $28^{\circ} \mathrm{C}$, $N=111$; Tanto $24^{\circ} \mathrm{C}, N=112$; Tanto $28^{\circ} \mathrm{C}, N=102$. The higher temperature causes a significant increase in the local cell-to-cell spread of infection in both Drakkar (ANOVA, $p=4,3^{-21}$ ) and Tanto (ANOVA, $p=2,5^{-37}$ ). (C) Systemic spread of TuMV-GFP in Drakkar is more efficient at $28^{\circ} \mathrm{C}$ (orange) than at $24^{\circ} \mathrm{C}$ (green). Inoculated leaves of nine plants at $24^{\circ} \mathrm{C}$ and of nine plants at $28^{\circ} \mathrm{C}$ were removed after 1,2 , or $3 \mathrm{dpi}$, followed by scoring the systemic leaves for GFP fluorescence (systemic infection) at $16 \mathrm{dpi}$. A control plant from which the inoculated leaf was not removed is shown in panel (D). (D) TuMV-GFP-infected Drakkar plant showing systemic infection at $21 \mathrm{dpi}$. The picture was taken under UV light.

ubiquitous in the wild and play an important role in the evolution of life. Surveys have shown that $60-70 \%$ of plants grown in natural ecosystems are infected with viruses (Roossinck, 2015).
Continuous host-virus co-evolution in natural habitats allows viruses to adapt to their hosts and maintain or even improve their fitness. Thus, plants in the wild are normally free of symptoms 
despite infection by viruses. Although a significant virus load is sustained in such virus-tolerant plants, the plant growth, yield, or reproduction attributes are only minimally affected and visible symptoms are either absent or mild (Pagan and Garcia-Arenal, 2018; Paudel and Sanfacon, 2018). However, tolerance, thus the ability of the infected plant to reduce negative effects of the infection, is a complex and highly evolved trait that depends on a well-adjusted host-virus crosstalk (Kørner et al., 2018; Paudel and Sanfacon, 2018; Pitzalis et al., 2020) and contributes to host fitness through multiple molecular mechanisms (Pagan and GarciaArenal, 2018, 2020). Higher average temperatures, leading to a more favorable environment for virus replication and movement, may break the delicate equilibrium between plant viruses and their hosts and thereby lead to the outbreak of new diseases. Such temperature-related loss of tolerance in crops and wild species and the spreading of new diseases from natural reservoirs toward crops may have important consequences for agriculture.

As humanity faces increasing average annual temperatures, it is important to understand the temperature-sensitive mechanisms that determine the propagation and spread of viruses within their hosts. The underlying mechanisms can be of a diverse nature. Apart from increased membrane fluidity and cytoskeletal dynamics that likely accelerate the membrane- and cytoskeleton-associated processes involved in virus replication and transport, temperature may also affect the regulation of the intercellular communication channels in the plant cell walls (plasmodesmata). Plasmodesmata (PD) are important gates through which viruses must move their genomes to spread infection between cells, into the phloem, and finally throughout the plant. In accordance with their central function in intercellular communication, PD are equipped with receptor proteins and receptor protein kinases that form signaling hubs through which PD are enabled to orchestrate processes related to plant growth and development but also responses to pathogens and abiotic stresses (Lee, 2015; Stahl and Faulkner, 2016). A recent study highlights the ability of PD to recruit receptor-like kinases in response to osmotic stress (Grison et al., 2019). It seems feasible, therefore, that changes in temperature can lead to specific alterations in the composition and regulation of PD, which in turn likely affects virus spread from cell to cell. So far, there are only few studies addressing the specific effects of temperature on PD function. Studies in poplar revealed that temperature influences the expression of dormancy-related genes, including gibberellin-acid (GA)-inducible members of beta-1,3-glucanase family involved in the degradation of callose at the plasmodesmal dormancy sphincter complexes (Rinne et al., 2011, 2018). Effects of temperature on PD structure and conductivity were also observed in maize (Bilska and Sowinski, 2010). Recent progress made in the analysis of PD structure, composition, and regulation (Wu et al., 2018; Brault et al., 2019; Grison et al., 2019; Huang et al., 2019; Cheval et al., 2020; Iswanto et al., 2020; Liu et al., 2020) may facilitate future research in model systems such as $N$. benthamiana and Arabidopsis to reveal the impact of increasing temperature on PD proteins and membranes and whether such changes correlate with an altered flow of PD targeted and non-targeted macromolecules (e.g., GFP) through the pore.
Warmer temperature may facilitate virus spread also by altering the activity or turnover of the viral movement proteins (MPs), which may affect the interaction of viruses with PD. The mentioned increased efficiency of intercellular spread of TMV in $N$. benthamiana at higher temperature correlated with changes in the subcellular accumulation pattern of the virus-encoded, GFPtagged MP (Boyko et al., 2000b). During infection the protein is expressed in distinct cortical endoplasmic reticulum (cortical ER)-associated replication complexes that are formed at sites of the cortical ER at which this membrane network intersects with cortical microtubules (Niehl et al., 2013). At the lower temperature $\left(22^{\circ} \mathrm{C}\right)$ the MP tends to stay and over-accumulate in the replication complexes that can grow to large sizes over time (Padgett et al., 1996; Heinlein et al., 1998; Niehl et al., 2013; Heinlein, 2015). At the higher temperature $\left(32^{\circ} \mathrm{C}\right)$, however, the MP accumulates along microtubules rather than in the replication complexes (Boyko et al., 2000b). The ability of MP to interact with microtubules is involved in virus movement and has been correlated with the formation and mobility of distinct MPcontaining replication complexes during early stages of infection in cells at the infection front (Boyko et al., 2000a, 2007; Niehl et al., 2014). Accumulation of high amounts of MP along the length of microtubules, in contrast, is dispensable for movement and is rather linked to its degradation in cells having completed the movement process (Gillespie et al., 2002; Niehl et al., 2012). The degradation of MP is triggered by its accumulation in the ER and depends on CDC48, an ATP-driven machinery that controls ER homeostasis by extracting over-accumulating or misfolded proteins from the membrane (Niehl et al., 2012). These observations are important in the context of other findings indicating that ER-associated virus replication and viral protein accumulation cause ER stress (Park and Park, 2019) and can lead to PD closure (Guenoune-Gelbart et al., 2008), thereby causing resistance against virus movement. Thus, by enhancing the removal of over-accumulated MP from the ER, which thereby results in the accumulated binding of MP along microtubules and promotes MP degradation, warmer temperature may avoid ER stress and PD closure, thereby facilitating efficient virus movement. Because of its direct binding affinity for microtubules (Ashby et al., 2006), the extraction of accumulated MP from the ER leads to its alignment along microtubules, which is directly or indirectly supported by another microtubule-associated protein (Curin et al., 2007). It is noteworthy that the movement of the TMV-related Oilseed rape mosaic virus (ORMV, also known as Youcai mosaic virus or TMV-Cg) is associated with the formation of distinct MP-containing, replication complexes during early stages of infection just like in the case of TMV. However, unlike the MP of TMV, the MP of ORMV does not accumulate on the ER or along microtubules. Importantly, this MP allows faster virus movement than the MP of TMV (Niehl et al., 2014). These observations are consistent with the conclusion that the enhanced TMV movement at higher temperature is associated with specific MP activities and turnover conditions.

Warmer temperature could affect TMV movement also by increasing myosin motor activity, thus facilitating the myosindriven transport of the virus and of MP along the ER-actin network to the PD (Hofmann et al., 2009; Amari et al., 2014). 
Temperature may also alter the ability of MP to bind RNA and other proteins, or to gate the PD channel. Potentially, such alterations in MP activity could be mediated through changes in the post-translational phosphorylation of the protein (Trutnyeva et al., 2005).

However, warmer temperatures may affect virus cell-tocell movement also more indirectly, for example, by causing changes in gene expression and alterations in the interactions of viruses with host defense responses. In plants carrying specific resistance $(\mathrm{R})$ genes, warmer temperature may indeed provoke stronger infections since resistance genes against biotrophic and hemi-biotrophic microbes (viruses, bacteria, fungi) are often temperature-sensitive and are inactivated at elevated temperature (Wang et al., 2009). Thus, in several plant-virus interactions, hypersensitive resistance (HR) or HR-like responses are slower when the temperature is elevated by a few degrees from $21-$ $22^{\circ} \mathrm{C}$ to $27-28^{\circ} \mathrm{C}$, and are lost at temperatures above $30^{\circ} \mathrm{C}$ (Whitham et al., 1996; Wang et al., 2009). In addition to R-gene mediated resistance, plants control their viruses also through pattern-triggered immunity (PTI) (Kørner et al., 2013; Niehl et al., 2016; Teixeira et al., 2019; Amari and Niehl, 2020) and RNA silencing (Ding, 2010; Pumplin and Voinnet, 2013). Both defense pathways are activated by dsRNA produced during virus infection. PTI involves the activation of transcriptional signaling that confers broad-spectrum pathogen resistance. In contrast, RNA silencing uses 21-24 nts long small interfering RNAs (siRNAs) and 21 nts microRNAs (miRNAs) to direct sequencespecific cleavage or translational repression of viral and host RNAs through ARGONAUTE (AGO)-containing RNA silencing effector complexes. While antiviral PTI has only recently been discovered and its sensitivity to temperature in the context of virus infection remains to be studied, RNA silencing has been reported to be more active at higher temperature and shown to be correlated with reduced disease symptoms in infected tissues (Szittya et al., 2003). However, other reports argue against such correlations or even conclude that RNA silencing or its systemic signaling is inhibited at elevated temperature (Zhong et al., 2013). These contrasting findings show that we are far from understanding how temperature influences the interaction of viruses with host defense pathways and that further studies are needed.

As already highlighted, global warming comes along with various other impacts on humidity, drought, rainfall intensity

\section{REFERENCES}

Amari, K., Di Donato, M., Dolja, V. V., and Heinlein, M. (2014). Myosins VIII and $\mathrm{XI}$ play distinct roles in reproduction and transport of tobacco mosaic virus. PLoS Pathog. 10:e1004448. doi: 10.1371/journal.ppat.1004448

Amari, K., and Niehl, A. (2020). Nucleic acid-mediated PAMP-triggered immunity in plants. Curr. Opin. Virol. 42, 32-39. doi: 10.1016/j.coviro.2020.04.003

Ashby, J., Boutant, E., Seemanpillai, M., Groner, A., Sambade, A., Ritzenthaler, C., et al. (2006). Tobacco mosaic virus movement protein functions as a structural microtubule-associated protein. J. Virol. 80, 8329-8344. doi: 10.1128/ JVI.00540-06

Bilska, A., and Sowinski, P. (2010). Closure of plasmodesmata in maize (Zea mays) at low temperature: a new mechanism for inhibition of photosynthesis. Ann. Bot. 106, 675-686. doi: 10.1093/aob/mcq169 and rainfall patterns, wind speed and direction, and greenhouse gas concentration. These parameters will result in altered crop cultivations systems and the range of cultivated species grown. This, in turn, will also influence the distribution of the viral insect vectors and plant hosts and, thereby, the distribution and evolution of virus species. However, while these long-term global consequences of climate change need to be studied, monitored, and modeled to improve disease management, changes in temperature have immediate effects on cellular mechanisms that are at the core of plant-virus interactions within each infected cell, irrespective of the region where the infected host is grown. This may aggravate diseases in natural and agricultural settings and damage yields and crop survival before temperatures will eventually exceed the host temperature tolerance ranges. To ensure agricultural yield, a concerted research effort is needed to understand the cellular mechanisms that determine disease tolerance in infected plants and to use this knowledge to adapt our crops toward temperature resilience and tolerance for viruses through dedicated breeding programs.

\section{DATA AVAILABILITY STATEMENT}

The original contributions presented in the study are included in the article/supplementary material, further inquiries can be directed to the corresponding author/s.

\section{AUTHOR CONTRIBUTIONS}

$\mathrm{CH}$ and $\mathrm{MH}$ wrote the manuscript. For Figure 2, $\mathrm{MH}$ conceived and designed the work. KA performed the acquisition and analysis of the data. All authors edited and approved the final version of the manuscript and agreed to be accountable for all aspects of the work.

\section{FUNDING}

Work shown in Figure 2 was supported by funding from the Agence National de la Recherche (Grant ANR-13-KBBE-00 05-01) and by a Ph.D. fellowship from the Chinese Scholarship Foundation (CSC) to $\mathrm{CH}$.

Bita, C. E., and Gerats, T. (2013). Plant tolerance to high temperature in a changing environment: scientific fundamentals and production of heat stress-tolerant crops. Front. Plant Sci. 4:273. doi: 10.3389/fpls.2013.00273

Boyko, V., Ferralli, J., Ashby, J., Schellenbaum, P., and Heinlein, M. (2000a). Function of microtubules in intercellular transport of plant virus RNA. Nat. Cell. Biol. 2, 826-832. doi: 10.1038/35041072

Boyko, V., Ferralli, J., and Heinlein, M. (2000b). Cell-to-cell movement of TMV RNA is temperature-dependent and corresponds to the association of movement protein with microtubules. Plant J. 22, 315-325.

Boyko, V., Hu, Q., Seemanpillai, M., Ashby, J., and Heinlein, M. (2007). Validation of microtubule-associated tobacco mosaic virus RNA movement and involvement of microtubule-aligned particle trafficking. Plant J. 51, 589-603. 
Brault, M. L., Petit, J. D., Immel, F., Nicolas, W. J., Glavier, M., Brocard, L., et al. (2019). Multiple C2 domains and transmembrane region proteins (MCTPs) tether membranes at plasmodesmata. EMBO Rep. 20, e47182. doi: 10.15252/ embr.201847182

Canto, T., Aranda, M. A., and Fereres, A. (2009). Climate change effects on physiology and population processes of hosts and vectors that influence the spread of hemipteran-borne plant viruses. Glob. Chang. Biol. 15, 1884-1894.

Cheval, C., Samwald, S., Johnston, M. G., de Keijzer, J., Breakspear, A., Liu, X., et al. (2020). Chitin perception in plasmodesmata characterizes submembrane immune-signaling specificity in plants. Proc. Natl. Acad. Sci. U. S. A. 117, 9621-9629. doi: 10.1073/pnas.1907799117

Choi, K. S., Del Toro, F., Tenllado, F., Canto, T., and Chung, B. N. (2017). A model to explain temperature dependent systemic infection of potato plants by potato virus Y. Plant Pathol. J. 33, 206-211. doi: 10.5423/PPJ.NT.06.2016.0144

Chung, B. N., Choi, K. S., Ahn, J. J., Joa, J. H., Do, K. S., and Park, K.-S. (2015). Effects of temperature on systemic infection and symptom expression of turnip mosaic virus in Chinese cabbage (Brassica campestris). Plant Pathol. J. 31, 363-370.

Curin, M., Ojangu, E. L., Trutnyeva, K., Ilau, B., Truve, E., and Waigmann, E. (2007). MPB2C, a microtubule-associated plant factor, is required for microtubular accumulation of tobacco mosaic virus movement protein in plants. Plant Physiol. 143, 801-811.

Ding, S. W. (2010). RNA-based antiviral immunity. Nat. Rev. Immunol. 10, 632644. doi: $10.1038 /$ nri2824

Gillespie, T., Boevink, P., Haupt, S., Roberts, A. G., Toth, R., Vantine, T., et al. (2002). Functional analysis of a DNA shuffled movement protein reveals that microtubules are dispensable for the cell-to-cell movement of tobacco mosaic virus. Plant Cell 14, 1207-1222.

Grison, M. S., Kirk, P., Brault, M. L., Wu, X. N., Schulze, W. X., Benitez-Alfonso, Y., et al. (2019). Plasma membrane-associated receptor-like kinases relocalize to plasmodesmata in response to osmotic stress. Plant Physiol. 181, 142-160. doi: 10.1104/pp.19.00473

Guenoune-Gelbart, D., Elbaum, M., Sagi, G., Levy, A., and Epel, B. L. (2008). Tobacco mosaic virus (TMV) replicase and movement protein function synergistically in facilitating TMV spread by lateral diffusion in the plasmodesmal desmotubule of Nicotiana benthamiana. Mol. Plant Microbe Interact. 21, 335-345. doi: 10.1094/MPMI-21-3-0335

Harrison, B. D. (1956). Studies on the effect of temperature on virus multiplication in inoculated leaves. Ann. Appl. Biol. 44, 215-226.

Heinlein, M. (2015). Plant virus replication and movement. Virology 47, 657-671. doi: 10.1016/j.virol.2015.01.025

Heinlein, M., Padgett, H. S., Gens, J. S., Pickard, B. G., Casper, S. J., Epel, B. L., et al. (1998). Changing patterns of localization of the tobacco mosaic virus movement protein and replicase to the endoplasmic reticulum and microtubules during infection. Plant Cell 10, 1107-1120.

Hofmann, C., Niehl, A., Sambade, A., Steinmetz, A., and Heinlein, M. (2009). Inhibition of tobacco mosaic virus movement by expression of an actin-binding protein. Plant Physiol. 149, 1810-1823. doi: 10.1104/pp.108.133827

Honjo, M. N., Emura, N., Kawagoe, T., Sugisaka, J., Kamitani, M., Nagano, A. J., et al. (2020). Seasonality of interactions between a plant virus and its host during persistent infection in a natural environment. ISME J. 14, 506-518. doi: 10.1038/s41396-019-0519-4

Huang, D., Sun, Y., Ma, Z., Ke, M., Cui, Y., Chen, Z., et al. (2019). Salicylic acidmediated plasmodesmal closure via Remorin-dependent lipid organization. Proc. Natl. Acad. Sci. U. S. A. 116, 21274-21284. doi: 10.1073/pnas.1911892116

IPCC (2014). Climate Change 2014: Synthesis Report. Contribution of Working Groups I, II and III to the Fifth Assessment Report of the Intergovernmental Panel on Climate Change. Geneva: IPCC.

Iswanto, A. B. B., Shon, J. C., Liu, K. H., Vu, M. H., Kumar, R., and Kim, J. Y. (2020). Sphingolipids modulate secretion of glycosylphosphatidylinositolanchored plasmodesmata proteins and callose deposition. Plant Physiol. 184, 407-420. doi: 10.1104/pp.20.00401

Jensen, S. G. (1973). Systemic movement of barley yellow dwarf virus in small grains. Phytopathology 63, 854-856.

Jones, R. A. C. (2020). Disease pandemics and major epidemics arising from new encounters between indigenous viruses and introduced crops. Viruses 12:1388. doi: $10.3390 / \mathrm{v} 12121388$
Jones, R. A. C., and Barbetti, M. J. (2012). Influence of climate change on plant disease infections and epidemics caused by viruses and bacteria. CAB Rev. 7, $1-32$.

Kørner, C. J., Klauser, D., Niehl, A., Dominguez-Ferreras, A., Chinchilla, D., Boller, T., et al. (2013). The immunity regulator BAK1 contributes to resistance against diverse RNA viruses. Mol. Plant Microbe Interact. 26, 1271-1280. doi: 10.1094/ MPMI-06-13-0179-R

Kørner, C. J., Pitzalis, N., Peña, E. J., Erhardt, M., Vazquez, F., and Heinlein, M. (2018). Crosstalk between PTGS and TGS pathways in natural antiviral immunity and disease recovery. Nat. Plants 4, 157-164. doi: 10.1038/s41477018-0117-x

Lebeurier, G., and Hirth, L. (1966). Effect of elevated temperatures on the development of two strains of tobacco mosaic virus. Virology 29, 385-395.

Lee, J. Y. (2015). Plasmodesmata: a signaling hub at the cellular boundary. Curr. Opin. Plant Biol. 27, 133-140. doi: 10.1016/j.pbi.2015.06.019

Liu, N. J., Zhang, T., Liu, Z. H., Chen, X., Guo, H. S., Ju, B. H., et al. (2020). Phytosphinganine affects plasmodesmata permeability via facilitating PDLP5stimulated callose accumulation in Arabidopsis. Mol. Plant 13, 128-143. doi: 10.1016/j.molp.2019.10.013

Nicaise, V. (2014). Crop immunity against viruses: outcomes and future challenges. Front. Plant Sci. 5:660. doi: 10.3389/fpls.2014.00660

Niehl, A., Amari, K., Gereige, D., Brandner, K., Mély, Y., and Heinlein, M. (2012). Control of tobacco mosaic virus movement protein fate by CELL-DIVISIONCYCLE protein 48 (CDC48). Plant Physiol. 160, 2093-2108. doi: 10.1104/pp. 112.207399

Niehl, A., Pasquier, A., Ferriol, I., Mely, Y., and Heinlein, M. (2014). Comparison of the oilseed rape mosaic virus and tobacco mosaic virus movement proteins (MP) reveals common and dissimilar MP functions for tobamovirus spread. Virology 45, 43-54. doi: 10.1016/j.virol.2014.03.007

Niehl, A., Pena, E. J., Amari, K., and Heinlein, M. (2013). Microtubules in viral replication and transport. Plant J. 75, 290-308. doi: 10.1111/tpj.12134

Niehl, A., Wyrsch, I., Boller, T., and Heinlein, M. (2016). Double-stranded RNAs induce a pattern-triggered immune signaling pathway in plants. New Phytol. 211, 1008-1019. doi: 10.1111/nph.13944

Padgett, H. S., Epel, B. L., Kahn, T. W., Heinlein, M., Watanabe, Y., and Beachy, R. N. (1996). Distribution of tobamovirus movement protein in infected cells and implications for cell-to-cell spread of infection. Plant J. 10, 1079-1088.

Pagan, I., and Garcia-Arenal, F. (2018). Tolerance to plant pathogens: theory and experimental evidence. Int. J. Mol. Sci. 19:810. doi: 10.3390/ijms19030810

Pagan, I., and Garcia-Arenal, F. (2020). Tolerance of plants to pathogens: a unifying view. Annu. Rev. Phytopathol. 58, 77-96. doi: 10.1146/annurev-phyto-010820012749

Parent, B., and Tardieu, F. (2012). Temperature responses of developmental processes have not been affected by breeding in different ecological areas for 17 crop species. New Phytol. 194, 760-774. doi: 10.1111/j.1469-8137.2012.04086.x

Park, C. J., and Park, J. M. (2019). Endoplasmic reticulum plays a critical role in integrating signals generated by both biotic and abiotic stress in plants. Front. Plant Sci. 10:399. doi: 10.3389/fpls.2019.00399

Paudel, D. B., and Sanfacon, H. (2018). Exploring the diversity of mechanisms associated with plant tolerance to virus infection. Front. Plant Sci. 9:1575. doi: 10.3389/fpls.2018.01575

Pitzalis, N., Amari, K., Graindorge, S., Pflieger, D., Donaire, L., Wassenegger, M., et al. (2020). Turnip mosaic virus in oilseed rape activates networks of sRNAmediated interactions between viral and host genomes. Commun. Biol. 3:702. doi: 10.1038/s42003-020-01425-y

Pumplin, N., and Voinnet, O. (2013). RNA silencing suppression by plant pathogens: defence, counter-defence and counter-counter-defence. Nat. Rev. Microbiol. 11, 745-760. doi: 10.1038/nrmicro3120

Rinne, P. L., Welling, A., Vahala, J., Ripel, L., Ruonala, R., Kangasjarvi, J., et al. (2011). Chilling of dormant buds hyperinduces FLOWERING LOCUS T and recruits GA-inducible 1,3-beta-glucanases to reopen signal conduits and release dormancy in Populus. Plant Cell 23, 130-146. doi: 10.1105/tpc.110.081307

Rinne, P. L. H., Paul, L. K., and van der Schoot, C. (2018). Decoupling photoand thermoperiod by projected climate change perturbs bud development, dormancy establishment and vernalization in the model tree Populus. BMC Plant Biol. 18:220. doi: 10.1186/s12870-018-1432-0

Roossinck, M. J. (2015). Plants, viruses and the environment: ecology and mutualism. Virology 47, 271-277. doi: 10.1016/j.virol.2015.03.041 
Ruelland, E., and Zachowski, A. (2010). How plants sense temperature. Environ. Exp. Bot. 69, 225-232.

Stahl, Y., and Faulkner, C. (2016). Receptor complex mediated regulation of symplastic traffic. Trends Plant Sci. 21, 450-459. doi: 10.1016/j.tplants.2015.11. 002

Szittya, G., Silhavy, D., Molnar, A., Havelda, Z., Lovas, A., Lakatos, L., et al. (2003). Low temperature inhibits RNA silencing-mediated defence by the control of siRNA generation. EMBO J. 22, 633-640.

Teixeira, R. M., Ferreira, M. A., Raimundo, G. A. S., Loriato, V. A. P., Reis, P. A. B., and Fontes, E. P. B. (2019). Virus perception at the cell surface: revisiting the roles of receptor-like kinases as viral pattern recognition receptors. Mol. Plant Pathol. 20, 1196-1202. doi: 10.1111/mpp.12816

Trutnyeva, K., Bachmaier, R., and Waigmann, E. (2005). Mimicking carboxyterminal phosphorylation differentially effects subcellular distribution and cell-to-cell movement of tobacco mosaic virus movement protein. Virology 332, 563-577.

Wang, Y., Bao, Z., Zhu, Y., and Hua, J. (2009). Analysis of temperature modulation of plant defense against biotrophic microbes. Mol. Plant Microbe Interact. 22, 498-506. doi: 10.1094/MPMI-22-5-0498

Whitham, S., McCormick, S., and Baker, B. (1996). The N gene of tobacco confers resistance to tobacco mosaic virus in transgenic tomato. Proc. Natl. Acad. Sci. U. S. A. 93, 8776-8781.
Wosula, E. N., Tatineni, S., Wegulo, S. N., and Hein, G. L. (2017). Effect of temperature on wheat streak mosaic disease development in winter wheat. Plant Dis. 101, 324-330. doi: 10.1094/PDIS-07-16-105 3-RE

Wu, S. W., Kumar, R., Iswanto, A. B. B., and Kim, J. Y. (2018). Callose balancing at plasmodesmata. J. Exp. Bot. 69, 5325-5339. doi: 10.1093/jxb/er y317

Zhong, S. H., Liu, J. Z., Jin, H., Lin, L., Li, Q., Chen, Y., et al. (2013). Warm temperatures induce transgenerational epigenetic release of RNA silencing by inhibiting siRNA biogenesis in Arabidopsis. Proc. Natl. Acad. Sci. U. S. A. 110, 9171-9176. doi: 10.1073/pnas. 1219655110

Conflict of Interest: The authors declare that the research was conducted in the absence of any commercial or financial relationships that could be construed as a potential conflict of interest.

Copyright (c) 2021 Amari, Huang and Heinlein. This is an open-access article distributed under the terms of the Creative Commons Attribution License (CC BY). The use, distribution or reproduction in other forums is permitted, provided the original author(s) and the copyright owner(s) are credited and that the original publication in this journal is cited, in accordance with accepted academic practice. No use, distribution or reproduction is permitted which does not comply with these terms. 